\title{
Occurrence and distribution of heavy metals and tetracyclines in agricultural soils after typical land use change in east China
}

\author{
Longhhua Wu • Xia Pan • Like Chen • Yujuan Huang • \\ Ying Teng • Yongming Luo • Peter Christie
}

Received: 11 December 2012 / Accepted: 28 January 2013 /Published online: 14 February 2013

(C) Springer-Verlag Berlin Heidelberg 2013

\begin{abstract}
Land use in east China tends to change from paddy rice to vegetables or other high-value cash crops, resulting in high input rates of organic manures and increased risk of contamination with both heavy metals (HMs) and antibiotics. This investigation was conducted to determine the accumulation, distribution and risks of HMs and tetracyclines (TCs) in surface soils and profiles receiving different amounts of farmyard manure. Soil samples collected from suburbs of Hangzhou city, Zhejiang province were introduced to represent three types of land use change from paddy rice to asparagus production, vineyards and field mustard cultivation, and divided into two portions, one of which was air-dried and sieved through 2-, 0.3- and 0.149-mm nylon mesh for determination of $\mathrm{pH}$ and heavy metals. The other portion was frozen at $-20{ }^{\circ} \mathrm{C}$, freeze-dried and sieved through a $0.3-\mathrm{mm}$ nylon mesh for tetracyline determination. HM and TC concentrations in surface soils of 14-year-old mustard fields were the highest with total $\mathrm{Cu}, \mathrm{Zn}, \mathrm{Cd}$ and $\sum \mathrm{TCs}$ of 50.5, 196,
\end{abstract}

Responsible editor: Philippe Garrigues

L. Wu $(\bowtie) \cdot$ X. Pan $\cdot$ L. Chen $\cdot$ Y. Huang $\cdot$ Y. Teng $\cdot$ Y. Luo Key Laboratory of Soil Environment and Pollution Remediation, Institute of Soil Science, Chinese Academy of Sciences, Nanjing 210008, People's Republic of China

e-mail: 1hwu@issas.ac.cn

X. Pan

University of Chinese Academy of Sciences,

Beijing 100049, People's Republic of China

Y. Luo

Yantai Institute of Coastal Zone Research, Chinese Academy

of Sciences, Yantai 264003, People's Republic of China

P. Christie

Agri-Environment Branch, Agri-Food and Biosciences Institute,

Newforge Lane,

Belfast BT9 5PX, UK
$1.03 \mathrm{mgkg}^{-1}$ and $22.9 \mu \mathrm{gkg}^{-1}$, respectively, on average. The total $\mathrm{Cu}$ sequence was field mustard $>$ vineyards $>$ asparagus when duration of land use change was considered; oxytetracycline (OTC) and doxycycline were dominant in soils used for asparagus production; OTC was dominant in vineyards and chlortetracycline (CTC) was dominant in mustard soils. There were positive pollution relationships among $\mathrm{Cu}, \mathrm{Zn}$ and $\sum \mathrm{TCs}$, especially between $\mathrm{Cu}$ and $\mathrm{Zn}$ or $\mathrm{Cu}$ and $\sum$ TCs. Repeated and excessive application of manures from intensive farming systems may produce combined contamination with HMs and TCs which were found in the top $20 \mathrm{~cm}$ of the arable soil profiles and also extended to $20-40 \mathrm{~cm}$ depth. Increasing manure application rate and cultivation time led to continuing increases in residue concentrations and movement down the soil profile.

Keywords Heavy metals $\cdot$ Tetracyclines $\cdot$ Farmyard manure $\cdot$ Land use change $\cdot$ Cropping systems $\cdot$ Correlation analysis

\section{Introduction}

Land application of farmyard manure is a common practice in many parts of the world as a means of recycling plant nutrients in crop production as well as a method of disposing of unwanted waste (Pinamonti et al. 1997; Kirchmann and Thorvaldsson 2000; Kumar et al. 2005a). However, the intensification of animal husbandry has led to the use of feed additives such as heavy metals and veterinary antibiotics to control animal diseases in all classes of livestock including poultry (Arthur et al. 1982; Nicholson et al. 1999; Kumar et al. 2005b; Chen et al. 2012a, b). Our recent results show that pig manure from intensively managed pig farms led to the accumulation of $\mathrm{Cd}$ in both exchangeable and reducible soil 
fractions ( $\mathrm{Wu}$ et al. 2012). There is increasing concern over the possible environmental consequences of applying livestock manures containing inorganic additives and the residues of organic contaminants derived from animal feedstuffs (Phillips et al. 2004; Knapp et al. 2010; Hu et al. 2010; Lopes et al. 2011).

Most heavy metals are added to animal feeds to prevent disease and increase weight gain and feed conversion, but they are largely expelled in the faeces and urine (Tufft and Nockels 1991; Bolan et al. 2004). Kornegay et al. (1976) observed that more than $90 \%$ of the $\mathrm{Cu}$ in animal diets was lost in the faeces. Manures have become an important source of heavy metals applied to agriculture land, accounting for approximately $40 \%$ of total annual inputs of $\mathrm{Zn}$ and $\mathrm{Cu}$ to agricultural land and $11 \%$ of $\mathrm{Cd}$ inputs (Veeken and Hamelers 2002; Nicholson et al. 2003). Veterinary antibiotics are also widely employed to control infections of animals in intensive farming systems (Halling-Sorensen et al. 1998; Boxall et al. 2003). The use of veterinary antibiotics has reached approximately 6,000 tonnes annually in China (Zhao et al. 2010). However, because of their low absorption by animals, up to $30-90 \%$ of the parent compounds or their metabolites are expelled in faeces and urine when some of them are still biologically active (Bound and Voulvoulis 2004; Sarmah et al. 2006; Zhou et al. 2006).

The tetracyclines (TCs) are a group of broad-spectrum antibiotics which are widely used as antibacterial agents in veterinary medicine. They are active against a range of organisms such as mycoplasma and chlamydia together with a number of Gram-positive and Gram-negative bacteria. In recent years, the occurrence and fate of antibiotics in soils have received increasing attention. Hamscher et al. (2002) found a maximum concentration of tetracycline in soils amended with manure of $199 \mu \mathrm{gkg}^{-1}$. Up to $1,000 \mu \mathrm{gkg}^{-1}$ of oxytetracycline was detected in soil amended with antibiotic-contaminated pig manure (Brambilla et al. 2007). Li et al. (2011) found that the total concentrations of tetracyclines in $35 \%$ of soils sampled exceeded $100 \mathrm{\mu gkg}^{-1}$ and the highest value was $243 \mu \mathrm{gkg}^{-1}$. There is increasing concern about residues of veterinary antibiotics in soils because of the spread of antibiotic resistance genes in the environment (Martinez 2008). Heavy metals and antibiotics in soils may affect the stability and productivity of soil ecosystems, harm plant growth, influence the safety of the human food chain and promote the emergence of micro-organisms with antibiotic resistance genes (ARGs) (Abaye et al. 2005; Wei et al. 2009; Boxall et al. 2003; Sarmah et al. 2006; Berenguer et al. 2008; Chee-Sanford et al. 2009).

Most studies have reported the concentrations of either heavy metals or antibiotics in soils and their environmental risks. Few have investigated both types of contaminant together. The main objectives of the present study were therefore to investigate combined pollution by heavy metals and tetracyclines in farmland following manure application, and to study the effects of land use change and cultivation time on the distribution and migration of these pollutants. Many rice paddy fields in China have been converted to production of cash crops because of the pressures of limited land resources and the increasing population (Shi et al. 2002). This may lead to substantial modifications in the biological and chemical properties of soils and result in changes in the distribution and transformation of pollutants (Voundi Nkana and Tonye 2003; Fernandez-Calvino et al. 2008).

\section{Materials and methods}

Sampling location and sample collection

The Yangtze River Delta is situated in east China and includes (from north to south) Jiangsu province, Shanghai city and Zhejiang province. The climate is subtropical monsoon with four distinct seasons. Annual average temperatures range from 16 to $18{ }^{\circ} \mathrm{C}$ and annual average rainfall ranges from 800 to $1,600 \mathrm{~mm}$. Paddy fields represent the predominant land use in this region together with cultivated dry land, woodland and scrub, and wasteland. The sampling area at Fuyang city comprises an area of $10 \mathrm{~km}^{2}$ in central Zhejiang province containing several small commercial enterprises and is surrounded by hills. The area contains several villages linked by trunk roads and rivers, and can be considered to be fairly representative of the region.

One hundred and forty seven soil samples were collected, comprising surface soils $(0-15 \mathrm{~cm})$ and profiles $(0-100 \mathrm{~cm})$, in March 2011 soon after the crops were introduced. There were three types of land use change, namely from paddy rice to asparagus (Asparagus officinalis L.) fields (72 samples), vineyards (Vitis vinifera L.) (39 samples) and field mustard (Brassica campestris L.) fields (36 samples), and the different periods of cultivation of each land use type since conversion from paddy rice were also considered. Preliminary investigation showed that the asparagus fields received 4560 tonnes $\mathrm{ha}^{-1}$ of fresh manures as basal fertiliser, then 3 tonnes $\mathrm{ha}^{-1}$ of commercial organic fertilisers were top dressed; vineyards received 75 tonnes ha ${ }^{-1}$ of fresh manures as basal fertiliser, then 45 tonnes $\mathrm{ha}^{-1}$ of fresh manure or 4.5 tonnes ha ${ }^{-1}$ of commercial organic fertiliser were top dressed; in mustard fields, the application rates were 45 tonnes $\mathrm{ha}^{-1}$ year $^{-1}$ of fresh manure; and in paddy rice fields, no manure was applied. The soil type of the original paddy rice fields was Typic Fe-leachi-Stagnic Anthrosols according to the Chinese Soil Taxonomy Classification System (Cooperative Research Group on Chinese Soil Taxonomy 2001). Soil from all three land use types was collected from two locations in Fuyang, from asparagus fields $\left(\mathrm{A}=30^{\circ} 03^{\prime} \mathrm{N}, 119^{\circ} 59^{\prime} \mathrm{E}\right)$ and vineyards $\left(\mathrm{B}=30^{\circ} 04^{\prime} \mathrm{N}\right.$, 
Fig. 1 Location of the study area in Fuyang city, Zhejiang province, east China

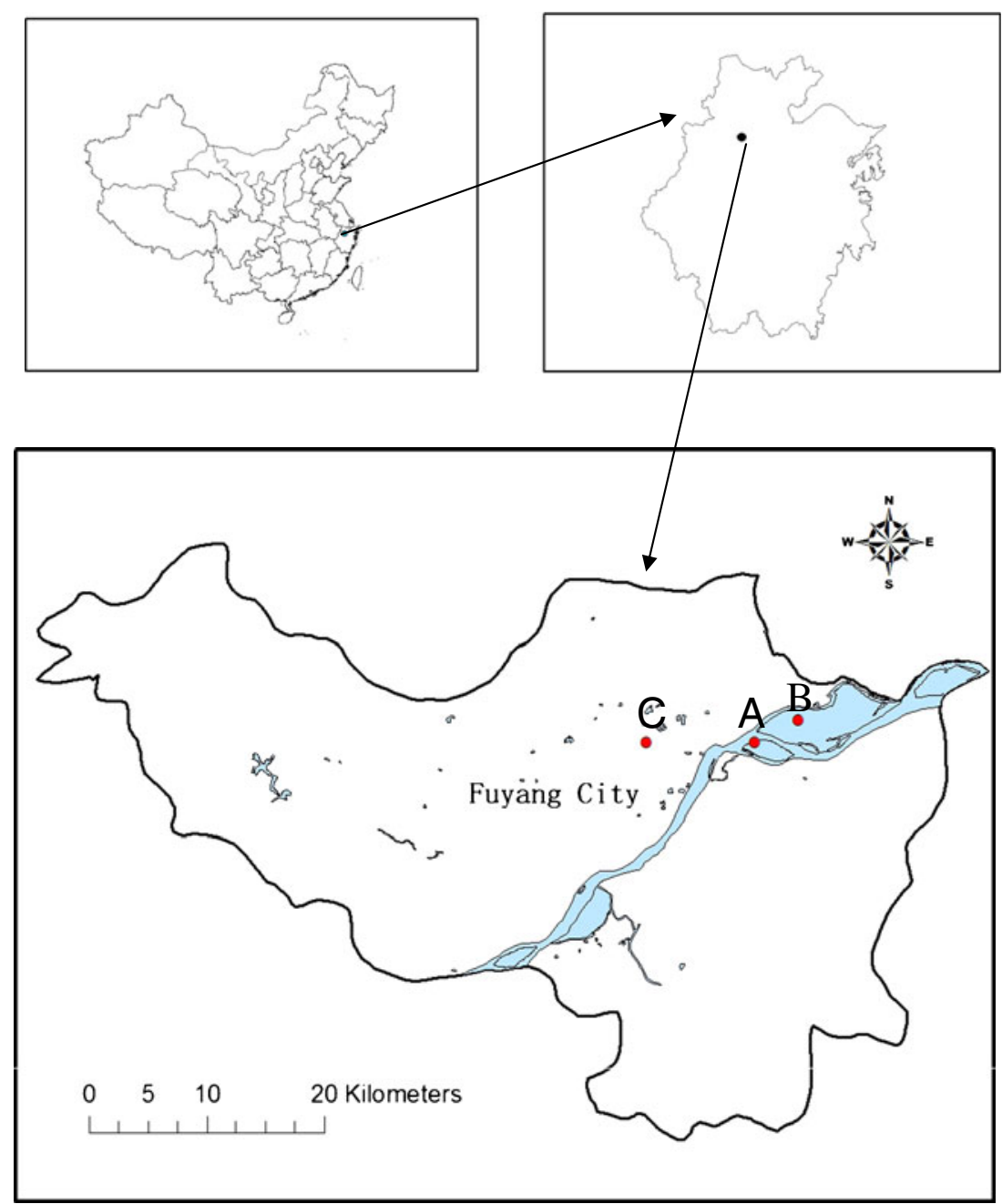

$120^{\circ} 01^{\prime} \mathrm{E}$ ) on a small island in Fuchunjiang River, and from mustard fields $\left(\mathrm{C}=30^{\circ} 03 \mathrm{~N}, 119^{\circ} 54^{\prime} \mathrm{E}\right) 5 \mathrm{~km}$ from the north bank of the river (Fig. 1). The asparagus was planted in polytunnel greenhouses, but the mustard was grown in open fields. Samples were also collected from long-term paddy rice fields at three locations to act as controls and named controls 1-3. Each control was matched to one type of land use, and the distance between each land use type and its paddy rice field control was at least $500 \mathrm{~m}$. Samples were collected from asparagus fields cultivated for 8,13 and 23 years, from vineyards established for 10 and 22 years, and from mustard fields cultivated for 14 years. Surface soil samples were collected from the plough layer (top $15 \mathrm{~cm}$ ) of the soil profile and profile soil samples were collected to a depth of $100 \mathrm{~cm}$ at 20-cm intervals using a stainless steel corer. In each mustard field and vineyard, three surface samples, one from each corner of a triangle, were collected and their average value used to represent the sampling site. The distance between the three samples was about $20 \mathrm{~m}$; for each composite sample, three cores from the points of a $1 \times 1 \mathrm{~m}$ triangle were mixed. Each asparagus field was divided into three transects $1.5 \mathrm{~m}$ apart and one sample was collected from one transect; in each transect, three cores from south to east $5 \mathrm{~m}$ apart were mixed to give a composite sample. The profile soil samples were collected in the same way. A total of 18 composite samples were collected from each asparagus or mustard field or 22year-old vineyard, three surface samples and three profiles (15 samples each). Only three surface samples were collected
Table 1 Optimized MS/MS parameters for the target antibiotics

\begin{tabular}{lllll}
\hline Compound & Abbreviation & Molecular weight & Parent $(\mathrm{m} / \mathrm{z})$ & Daughter $(\mathrm{m} / \mathrm{z})$ \\
\hline Tetracycline & TC & 444.5 & 445.3 & $154.3,410.3$ \\
Oxytetracycline & OTC & 460.4 & 461.3 & $426.3,443.3$ \\
Chlortetracycline & CTC & 478.9 & 479.1 & $154.2,444.3$ \\
Doxycycline & DOC & 444.5 & 445.1 & $154.2,428.3$ \\
\hline
\end{tabular}


Table 2 Recoveries of selected antibiotics in soils

\begin{tabular}{lllll}
\hline $\begin{array}{l}\text { Concentration } \\
\left(\mu \mathrm{gkg}^{-1}\right)\end{array}$ & \multicolumn{2}{l}{ Recovery } & & \\
\cline { 2 - 5 } & $\mathrm{TC}$ & OTC & CTC & DOC \\
\hline 5 & $0.56 \pm 0.07$ & $0.94 \pm 0.11$ & $0.56 \pm 0.08$ & $0.95 \pm 0.10$ \\
10 & $0.54 \pm 0.02$ & $0.89 \pm 0.04$ & $0.58 \pm 0.03$ & $0.89 \pm 0.05$ \\
20 & $0.63 \pm 0.03$ & $0.99 \pm 0.04$ & $0.66 \pm 0.02$ & $1.04 \pm 0.06$ \\
50 & $0.65 \pm 0.01$ & $1.05 \pm 0.02$ & $0.62 \pm 0.02$ & $0.90 \pm 0.04$ \\
\hline
\end{tabular}

The data are mean value \pm standard error of the mean $(n=3)$

from the 10-year-old vineyards. The sampling positions were recorded using a global positioning system.

Sample preparation and analysis

After collection, the soil samples were sealed in plastic bags, placed in a portable cooler and transported to the laboratory. About $100 \mathrm{~g}$ of each sample was taken for freeze-drying using a FreeZone 2.5L Freeze Dry System (Labconco Corp., Kansas City, MO, USA) and then ground to pass through a $0.3-\mathrm{mm}$ sieve and homogenised before extraction. The remainder of each sample was air-dried at room temperature, cleared of stones and visible plant materials, and sieved through a 2-mm nylon mesh for soil $\mathrm{pH}$ determination. The sieved soil was then passed through $0.3-\mathrm{mm}$ and $0.15-\mathrm{mm}$ nylon mesh sieves for determination of heavy metals.

\section{Soil aqua regia- and $\mathrm{HCl}$-extractable heavy metal concentrations}

Soil sub-samples were digested with 4:1 (v/v) $\mathrm{HCI} / \mathrm{HNO}_{3}$ according to McGrath and Cunliffe (1985). Metals were extracted with $0.1 \mathrm{M} \mathrm{HCl}$ solution and the soil-liquid ratio was 1:5. Concentrations of $\mathrm{Zn}$ and $\mathrm{Cu}$ were determined by flame atomic absorption spectrophotometry (Varian SpectrAA 220 FS) and Cd with a Varian SpectrAA 220Z spectrophotometer equipped with a graphite furnace.

\section{Soil tetracylines}

The method of Chen et al. (2012a) was used, with $5.00 \mathrm{~g}$ aliquots of soil ultrasonically extracted in glass centrifuge tubes with $30 \mathrm{ml}$ of 1:1 (v/v) methanol/EDTA-McIlvaine buffer (pH4.0) for $40 \mathrm{~min}$. Extracts were then separated by centrifugation, and the process was repeated three times. For the second and third extractions, the volume of extractant was $30 \mathrm{ml}$ and the sonication time was $30 \mathrm{~min}$. Supernatants were combined and evaporated to half of the original volume (total $70 \mathrm{ml}$ ) using a rotary evaporator to remove the methanol. The residual liquid was then diluted to $100 \mathrm{ml}$. Diluents were cleaned up and extracted using SAX-HLB SPE cartridges set up in tandem and pre-conditioned sequentially with $10 \mathrm{ml}$ of methanol and $10 \mathrm{ml}$ of ultrapure water, at a flow rate of approximately $5.0 \mathrm{mlmin}^{-1}$. Samples were then passed through SPE columns at a flow rate of approximately $3.0 \mathrm{mlmin}^{-1}$. After the water had passed through the combined cartridges, the SAX columns were removed and the HLB cartridges were rinsed with $10 \mathrm{ml}$ of ultrapure water and dried under $\mathrm{N}_{2}$ gas for $30 \mathrm{~min}$ at a flow rate of 2-4 $\mathrm{mlmin}^{-1}$. After drying, each cartridge was eluted with $2 \mathrm{ml}$ methanol [containing $0.1 \%$ (v/v) formic acid] with a retention time of 2-3 min and then with $8 \mathrm{ml}$ methanol at a rate of $<3.0 \mathrm{mlmin}^{-1}$. Analytes were collected in a $15-\mathrm{ml}$ brown glass vial and the volume was reduced to less than $1.0 \mathrm{ml}$ by purging with $\mathrm{N}_{2}$. The final volume in each

Table 3 Changes in surface soil $\mathrm{pH}$ and heavy metals in soil samples from different land use types $\left(\mathrm{mgkg}^{-1}\right)$

\begin{tabular}{|c|c|c|c|c|c|c|c|c|}
\hline \multirow[t]{2}{*}{ Land use type } & \multirow{2}{*}{$\begin{array}{l}\text { Cultivation } \\
\text { period (years) }\end{array}$} & \multirow[t]{2}{*}{$\mathrm{pH}$} & \multicolumn{3}{|c|}{ Aqua regia extractable } & \multicolumn{3}{|c|}{$\mathrm{HCl}$ extractable } \\
\hline & & & $\mathrm{Cu}$ & $\mathrm{Zn}$ & $\mathrm{Cd}$ & $\mathrm{Cu}$ & $\mathrm{Zn}$ & $\mathrm{Cd}$ \\
\hline \multirow[t]{4}{*}{ Asparagus } & Control 1 & $5.2 \pm 0.0 \mathrm{~b}$ & $20.2 \pm 0.1 \mathrm{~b}$ & $103 \pm 1 b$ & $0.23 \pm 0.02 b$ & $8.20 \pm 0.02 \mathrm{a}$ & $7.10 \pm 0.27 b$ & $0.12 \pm 0.01 \mathrm{~b}$ \\
\hline & 8 & $6.3 \pm 0.2 \mathrm{a}$ & $18.7 \pm 1.6 b$ & $138 \pm 11 \mathrm{a}$ & $0.35 \pm 0.04 \mathrm{a}$ & $5.12 \pm 0.10 \mathrm{~b}$ & $35.0 \pm 4.4 \mathrm{a}$ & $0.39 \pm 0.09 \mathrm{a}$ \\
\hline & 13 & $4.8 \pm 0.2 b$ & $27.6 \pm 1.5 \mathrm{a}$ & $125 \pm 10 \mathrm{ab}$ & $0.22 \pm 0.01 \mathrm{~b}$ & $8.21 \pm 0.16 \mathrm{a}$ & $24.2 \pm 5.9 \mathrm{a}$ & $0.16 \pm 0.01 \mathrm{~b}$ \\
\hline & 23 & $5.4 \pm 0.3 b$ & $25.7 \pm 1.6 \mathrm{a}$ & $111 \pm 4 \mathrm{ab}$ & $0.20 \pm 0.04 b$ & $7.40 \pm 0.63 \mathrm{a}$ & $24.1 \pm 4.3 \mathrm{a}$ & $0.05 \pm 0.02 b$ \\
\hline \multirow[t]{3}{*}{ Vineyard } & Control 2 & $5.4 \pm 0.1 \mathrm{a}$ & $19.5 \pm 0.9 \mathrm{~b}$ & $97.4 \pm 2.7 \mathrm{a}$ & $0.26 \pm 0.01 \mathrm{a}$ & $7.09 \pm 0.15 b$ & $5.82 \pm 0.02 \mathrm{a}$ & $0.19 \pm .01 \mathrm{a}$ \\
\hline & 10 & $5.0 \pm 0.2 \mathrm{a}$ & $20.9 \pm 1.1 \mathrm{~b}$ & $118 \pm 5 \mathrm{a}$ & $0.32 \pm 0.06 \mathrm{a}$ & $5.39 \pm 0.27 \mathrm{c}$ & $22.7 \pm 4.3 \mathrm{a}$ & $0.07 \pm 0.01 \mathrm{~b}$ \\
\hline & 22 & $4.6 \pm 0.2 \mathrm{a}$ & $29.5 \pm 3.1 \mathrm{a}$ & $98.0 \pm 11.1 \mathrm{a}$ & $0.17 \pm 0.04 \mathrm{a}$ & $8.18 \pm 0.10 \mathrm{a}$ & $19.1 \pm 5.1 \mathrm{a}$ & $0.04 \pm 0.01 \mathrm{~b}$ \\
\hline \multirow[t]{2}{*}{ Mustard } & Control 3 & $6.3 \pm 0.0 \mathrm{a}$ & $29.3 \pm 0.2 b$ & $163 \pm 1 \mathrm{a}$ & $0.95 \pm 0.07 \mathrm{a}$ & $6.94 \pm 0.17 b$ & $15.8 \pm 0.6 \mathrm{~b}$ & $0.48 \pm 0.01 \mathrm{a}$ \\
\hline & 14 & $5.7 \pm 0.2 \mathrm{a}$ & $50.5 \pm 3.2 \mathrm{a}$ & $196 \pm 9 \mathrm{a}$ & $1.03 \pm 0.05 \mathrm{a}$ & $13.0 \pm 0.7 \mathrm{a}$ & $51.7 \pm 4.0 \mathrm{a}$ & $0.35 \pm 0.00 \mathrm{~b}$ \\
\hline Chinese standard $^{\mathrm{a}}$ & Grade II & $<6.5$ & 50 & 200 & 0.3 & - & - & - \\
\hline
\end{tabular}

The differences in soil $\mathrm{pH}$, and the concentrations of $\mathrm{Cu}, \mathrm{Zn}, \mathrm{Cd}$, respectively, were determined by Duncan's multiple range test, and significant differences $(p<0.05)$ are indicated by different letters in each column

${ }^{a}$ From State Environmental Protection Administration of China, SEPA (1995) 
Table 4 Changes in soil profile $\mathrm{pH}$ under different land use types

\begin{tabular}{lllllll}
\hline $\begin{array}{l}\text { Land use } \\
\text { type }\end{array}$ & $\begin{array}{l}\text { Cultivation } \\
\text { period (years) }\end{array}$ & $0-20 \mathrm{~cm}$ & $20-40 \mathrm{~cm}$ & $40-60 \mathrm{~cm}$ & $60-80 \mathrm{~cm}$ & $80-100 \mathrm{~cm}$ \\
\hline Asparagus & Control 1 & $5.4 \pm 0.1 \mathrm{a}$ & $6.3 \pm 0.1 \mathrm{a}$ & $6.6 \pm 0.1 \mathrm{a}$ & $6.6 \pm 0.1 \mathrm{a}$ & $6.6 \pm 0.2 \mathrm{a}$ \\
& 8 & $3.8 \pm 0.1 \mathrm{c}$ & $4.7 \pm 0.4 \mathrm{~b}$ & $5.3 \pm 0.5 \mathrm{~b}$ & $5.6 \pm 0.4 \mathrm{~b}$ & $5.5 \pm 0.2 \mathrm{~b}$ \\
& 13 & $4.1 \pm 0.1 \mathrm{bc}$ & $5.9 \pm 0.2 \mathrm{a}$ & $6.6 \pm 0.1 \mathrm{a}$ & $6.6 \pm 0.1 \mathrm{a}$ & $6.4 \pm 0.1 \mathrm{a}$ \\
& 23 & $4.6 \pm 0.4 \mathrm{~b}$ & $5.7 \pm 0.1 \mathrm{a}$ & $5.8 \pm 0.0 \mathrm{ab}$ & $6.1 \pm 0.1 \mathrm{ab}$ & $6.2 \pm 0.1 \mathrm{a}$ \\
Vineyard & Control 2 & $5.8 \pm 0.2 \mathrm{a}$ & $6.3 \pm 0.2 \mathrm{a}$ & $6.6 \pm 0.2 \mathrm{a}$ & $6.7 \pm 0.3 \mathrm{a}$ & $6.8 \pm 0.3 \mathrm{a}$ \\
& 22 & $4.1 \pm 0.3 \mathrm{~b}$ & $4.4 \pm 0.2 \mathrm{~b}$ & $5.2 \pm 0.1 \mathrm{~b}$ & $5.4 \pm 0.5 \mathrm{a}$ & $5.8 \pm 0.2 \mathrm{a}$ \\
Mustard & Control 3 & $6.2 \pm 0.2 \mathrm{a}$ & $7.5 \pm 0.1 \mathrm{a}$ & $7.6 \pm 0.2 \mathrm{a}$ & $7.6 \pm 0.1 \mathrm{a}$ & $7.6 \pm 0.1 \mathrm{a}$ \\
& 14 & $6.5 \pm 0.3 \mathrm{a}$ & $7.5 \pm 0.2 \mathrm{a}$ & $7.4 \pm 0.1 \mathrm{a}$ & $7.4 \pm 0.3 \mathrm{a}$ & $7.3 \pm 0.2 \mathrm{a}$ \\
\hline
\end{tabular}

vial was adjusted to exactly $1.0 \mathrm{ml}$ with methanol for liquid chromatography (LC) analysis.

Antibiotic residues were separated by HPLC (Shimadzu, Japan) and API 3200 triple quadrupole tandem mass spectrometry (AB SCIEX, Framingham, MA, USA). Separation of the four tetracyclines was performed with a $150 \mathrm{~mm} \times$ $4.6 \mathrm{~mm} \times 5.0 \mu \mathrm{m}$ Kromasil C18 column (Akzo Nobel, Sweden) at a constant temperature of $35{ }^{\circ} \mathrm{C}$. The mobile phase A consisted of $99.9 \%$ water and $0.1 \%$ formic acid, and mobile phase B consisted of $99.9 \%$ acetonitrile mixed with $0.1 \%$ formic acid. The gradient elution was set as follows: $0-1 \mathrm{~min}$ at $15 \% \mathrm{~B}, 1-2 \mathrm{~min}$ linear gradient to $30 \% \mathrm{~B}, 2-5$ min linear gradient to $40 \% \mathrm{~B}, 5-6$ min linear gradient to $50 \% \mathrm{~B}, 6-10$ min linear gradient to $80 \% \mathrm{~B}$ and maintained for $5 \mathrm{~min}$. The injection volume was $10 \mu \mathrm{l}$ and the flow rate was $0.8 \mathrm{mlmin}^{-1}$. Ionisation was performed in the positive mode for tetracyclines. MS/MS was operated at unit resolution in the multiple reactions monitoring mode. Source conditions were optimised as follows: spray voltage + $5,500 \mathrm{~V}$, transfer capillary temperature $650{ }^{\circ} \mathrm{C}$, curtain gas 138 $\mathrm{kPa}$, ion source gas $1.03 \mathrm{MPa}$ and ion source gas $1.86 \mathrm{MPa}$ (high-purity $\mathrm{N}_{2}$ was used as the collision gas).
Fig. 2 a-c Changes in soil profile aqua regia-extractable heavy metal concentrations under different land use types. a Asparagus fields
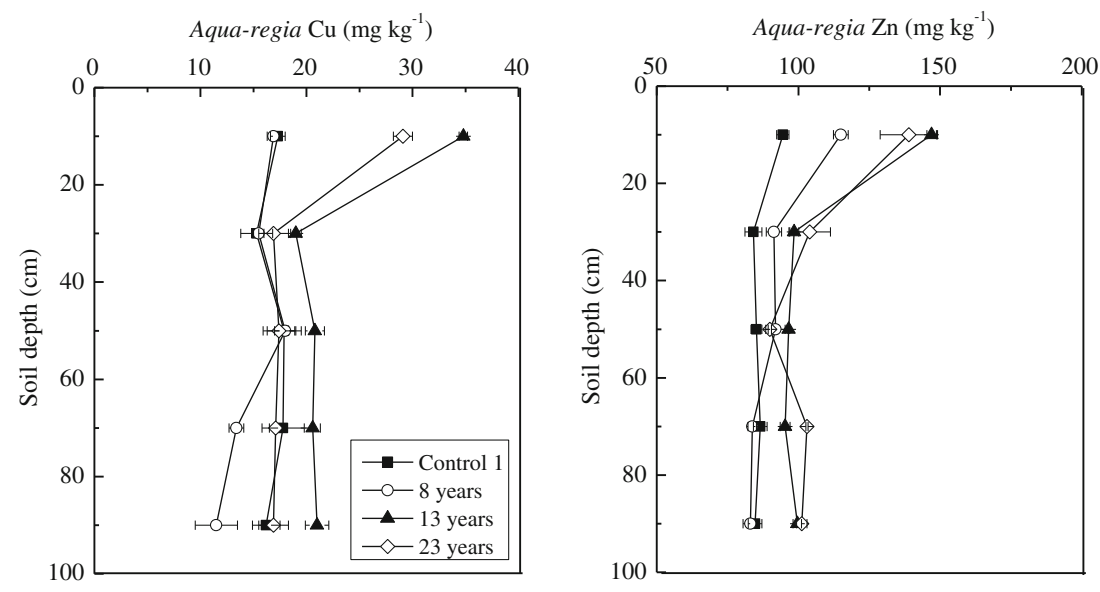

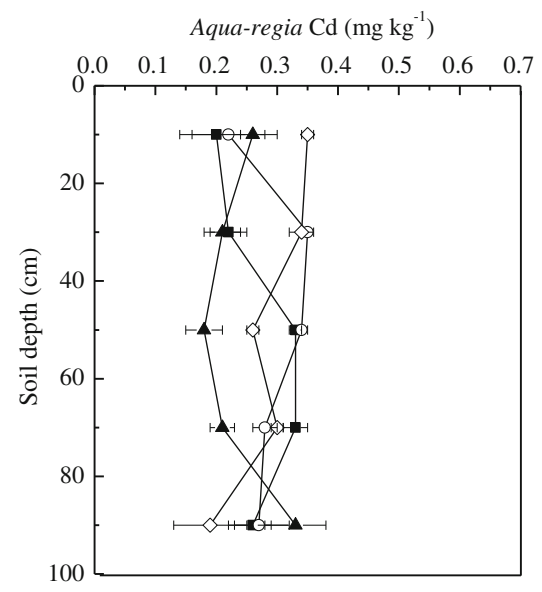


Chemicals and standards

Four selected antibiotic compounds were purchased from Sigma-Aldrich (St. Louis, MO, USA) (Table 1). HPLC-grade methanol, analytical-grade formic acid (99\%), citric acidmonohydrate, sodium phosphate-dibasic anhydrous and disodium ethylene diamine tetraacetic acid ( $\left.\mathrm{Na}_{2} \mathrm{EDTA}\right)$ were purchased from Sinopharm Chemical Reagent Co. Ltd. (Shanghai, China).

Individual stock solutions of all standards were prepared by dissolving $10 \mathrm{mg}$ of each antibiotic in $100 \mathrm{ml}$ of methanol $(\mathrm{MeOH})$. Standard solutions were stored in a freezer in amber vials and were freshly prepared every 3 months. Working standard mixtures were prepared immediately before the experiment by dilution of stock solutions and used for fortification in recovery experiments and for preparation of calibration standards. Ultrapure water was prepared with a Milli-Q water purification system (Millipore, Bedford, MA, USA). Oasis HLB cartridges, $6 \mathrm{ml} / 500 \mathrm{mg}$, used for solid-phase extraction (SPE), were purchased from Water Oasis Co. (Milford, MA, USA) and SAX cartridges ( $3 \mathrm{ml} / 500 \mathrm{mg}$ ) combined with HLB cartridges and used in wastewater preparation were sourced from Supelco (Bellefonte, PA, USA).
Quality assurance and quality control

For soil aqua regia-extractable metals, replicate samples, blanks and a certified reference soil material (GBW07404, provided by the Institute of Geophysical and Geochemical Exploration, Langfang city, Hebei province, China) were included in all analyses.

For tetracyclines, stock solutions were diluted to obtain $500 \mathrm{\mu gl}^{-1}$ standard mixtures for determination of recovery and 50,100, 200 and $500 \mu \mathrm{l}$ of standard mixture were added to $5 \mathrm{~g}$ soil to achieve antimicrobial concentrations of 5,10 , 20 and $50 \mu \mathrm{gkg}^{-1}$. Spiked soil samples were mixed thoroughly using a vortex mixer and kept in the dark overnight at room temperature to reach equilibrium state between antimicrobial compounds and soil matrices. The recovery results are shown in Table 2. Sample concentrations were calculated using an external standard method. Calibration lines of eight concentration points (1.0, 2.0, 5.0, 10.0, 20.0, 50.0, 100.0 and $200 \mathrm{\mu gl}^{-1}$ ) in methanol containing $0.1 \%$ $(\mathrm{v} / \mathrm{v})$ formic acid were used for quantification of the individual antibiotics. The linearity of the calibration curve in this range was confirmed by a high linear correlation coefficient $\left(R^{2}>0.99\right)$.
Fig. 3 a-c Changes in soil profile aqua regia-extractable heavy metal concentrations under different land use types. b Vineyards
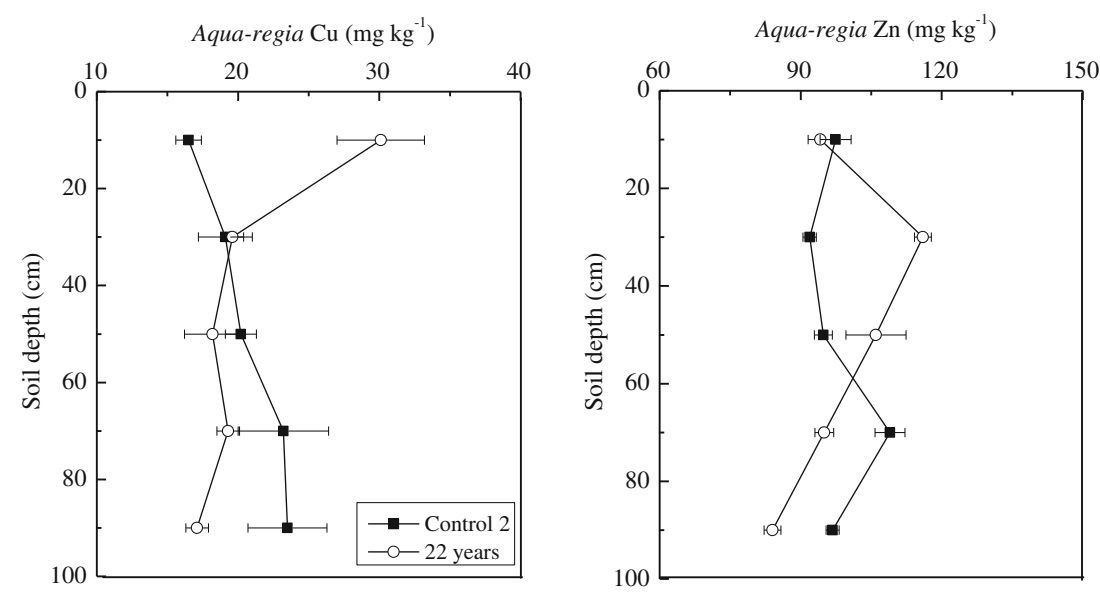

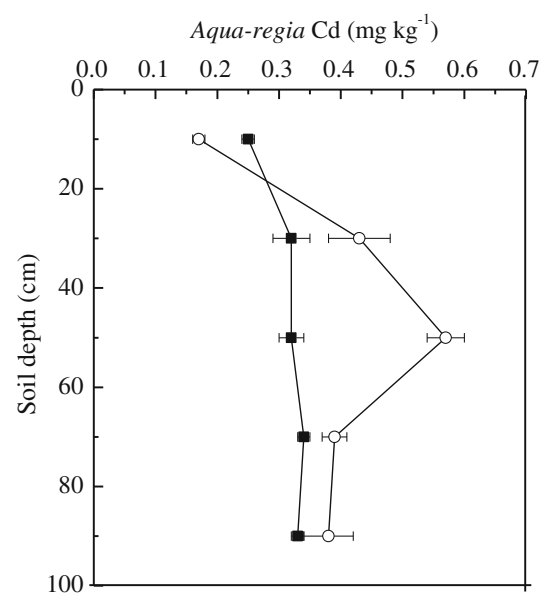


Statistical analysis

All statistical analyses were performed using SPSS software version 16.0 (SPSS Inc., Chicago, IL, USA). One-way analysis of variance was used for statistical comparisons and the Pearson coefficient was used for correlation analysis. A probability value of $P<0.05$ was considered to be statistically significant.

\section{Results}

Change in surface soil $\mathrm{pH}$ and heavy metal concentrations after change to different land use types

Surface soil $\mathrm{pH}$ and heavy metals under different land use types are presented in Table 3. There were no significant differences among the three types of land use change, except for the 8-year-old asparagus fields in which soil $\mathrm{pH}$ increased significantly compared to the control paddy soil but then decreased again with a further increase in cultivation time. In general, the three types of land use change investigated exerted no effect on soil $\mathrm{pH}$.
Comparing the three land use types, the concentrations of heavy meals in 14-year-old mustard fields were the highest and were related to high background values; total $\mathrm{Cu}, \mathrm{Zn}$ and Cd showed mean values of 50.5, 196 and $1.03 \mathrm{mg} \mathrm{kg}^{-1}$, respectively, and total $\mathrm{Cu}$ and $\mathrm{Cd}$ both exceeded grade II of the Chinese Soil Environmental Quality Standards (GB15618-1995) 1.01 and 3.43 times. The high total Cd may have been due to the high background value $(0.95 \mathrm{mg}$ $\mathrm{kg}^{-1}$ ) together with the soil available heavy metals, with mean values of available $\mathrm{Cu}, \mathrm{Zn}$ and $\mathrm{Cd}$ of 13.0, 51.7 and $0.35 \mathrm{mgkg}^{-1}$, respectively.

Statistically significant differences were found in total $\mathrm{Cu}$ and available $\mathrm{Zn}$ after land use change from paddy rice to asparagus production, and the longer the cultivation period, the larger the variation in values for total $\mathrm{Cu}$. Compared to the paddy soil (control 1), the concentrations of total $\mathrm{Cu}$ and available $\mathrm{Zn}$ increased 1.27 and 3.39 times, respectively. The changes in surface soils were related to type of heavy metal and cultivation period, and in the 8-year-old asparagus fields more significant differences were found, with total and available $\mathrm{Zn}$ and total and available $\mathrm{Cd}$ increasing and $\mathrm{Cd}$ at $0.35 \mathrm{mgkg}^{-1}$ also exceeding grade II of Standard
Fig. 4 a-c Changes in soil profile aqua regia-extractable heavy metal concentrations under different land use types. c Mustard fields
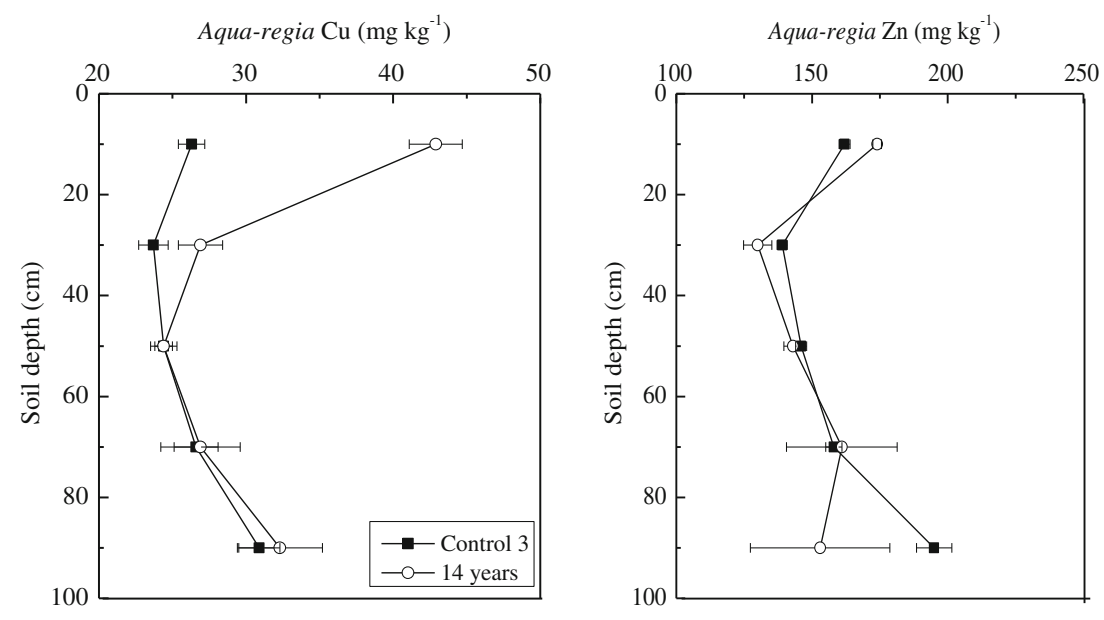

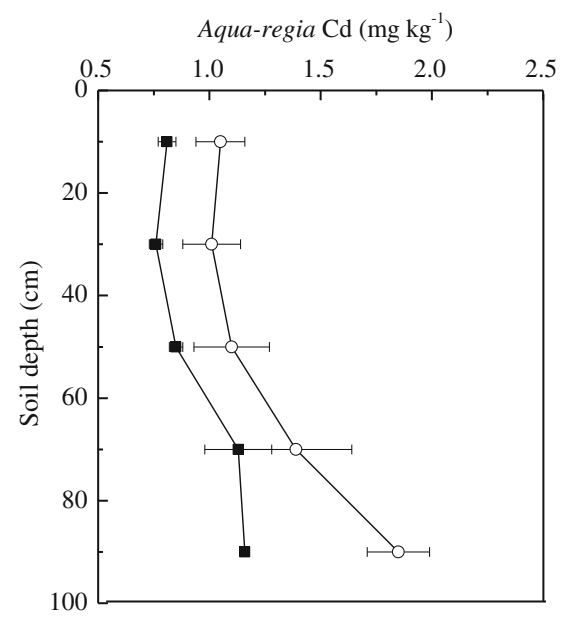


GB15618-1995. Soil HCl-extractable $\mathrm{Cu}$ decreased in 8year-old asparagus fields but did not differ from control 1 in the 13- and 23-year-old asparagus fields. When land use changed from paddy rice to viticulture, after long-term grape cultivation for about 22 years, the concentrations of total $\mathrm{Cu}$ also increased significantly and the accumulation was more than from paddy rice to asparagus production over a similar period, while available $\mathrm{Cu}$ increased by 1.15 times the paddy soil control (control 2) and available $\mathrm{Cd}$ decreased 4.75 times. The changes in heavy metals after land use change from paddy soil (control 3) to mustard production were similar to those from paddy rice to viticulture except that available $\mathrm{Zn}$ increased 3.27 times.

Changes in soil profile $\mathrm{pH}$ and heavy metal concentrations after change to different land use types

In general, soil $\mathrm{pH}$ decreased with increasing depth (Table 4). There were significant differences in the top $20 \mathrm{~cm}$ when land use changed from paddy rice field to asparagus production. After change to viticulture, soil $\mathrm{pH}$ also decreased significantly in the top three depth categories. Thus, these two types of land use change may lead to soil acidification, which may increase the available heavy metal fractions in the soil and increase environmental risk. Kumpiene et al. (2008) concluded that leaching of $\mathrm{Cu}, \mathrm{Zn}$ and $\mathrm{Pb}$ was strongly $\mathrm{pH}$ dependent, with lower mobility in neutral to slightly alkaline conditions.

Changes in soil profile total heavy metals are presented in Figs. 2, 3, 4 together with the background control (each a different long-term paddy rice field) for each new land use type. Generally, soil heavy metal concentrations decreased with increasing soil depth.

Significant increases were found in soil total $\mathrm{Cu}, \mathrm{Zn}$ and $\mathrm{Cd}$ with increasing cultivation time within each depth category of the soil profile with change from paddy rice to asparagus production, but this depended on the heavy metal and the cultivation period (Fig. 2). There were significant increases in total $\mathrm{Cu}$ in the top $20 \mathrm{~cm}$ of the soil profile after 13 years of asparagus cultivation and also between 13 and 23 years, but no significant differences between control 1 and 8 years. This indicates that accumulation of heavy metals was positively correlated with time, so that at 13 years the input was greater than the output. Total $\mathrm{Zn}$ increased in the top $40 \mathrm{~cm}$ with increasing cultivation period except between 13 and 23 years, possibly due to the relatively high mobility of soil $\mathrm{Zn}$. Significant increases in total $\mathrm{Cd}$ were found until 23 years in the top $20 \mathrm{~cm}$ and the concentrations were also above the
Fig. 5 a-c Changes in soil profile $\mathrm{HCl}$-extractable heavy metal concentrations under different land use types.

a Asparagus fields
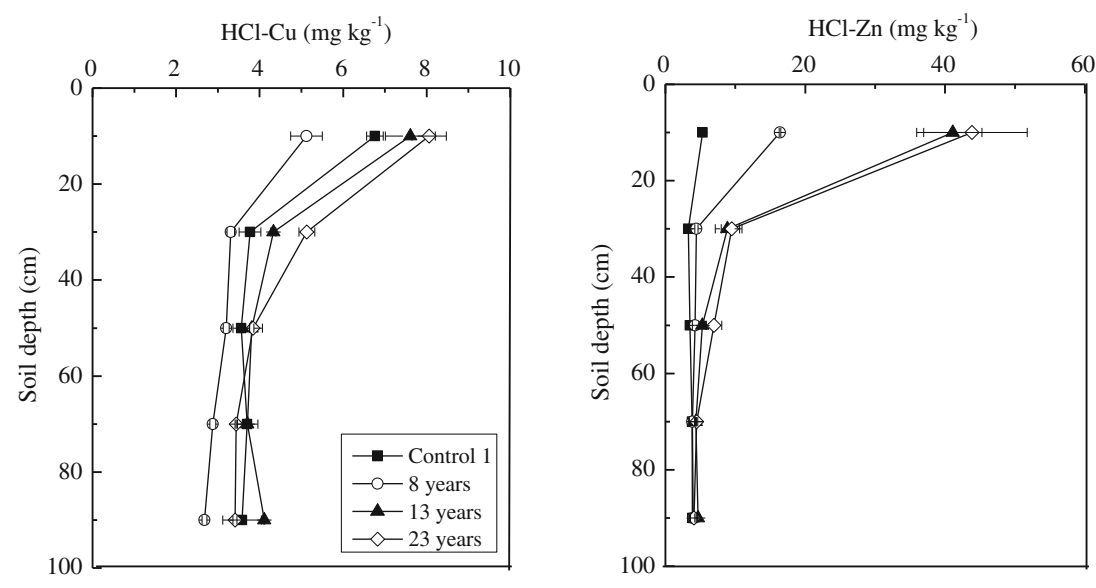

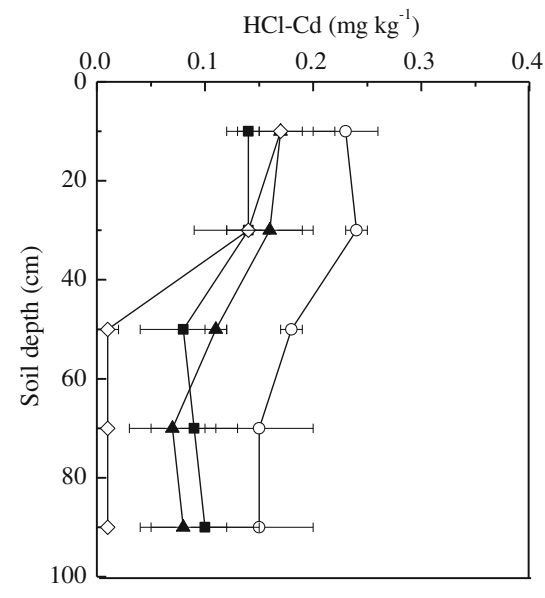


national standard. Significant increases in total $\mathrm{Cu}$ between the control 2 and 22 years of cultivation were found in the top $20 \mathrm{~cm}$ of the soil profile with change to viticulture while total $\mathrm{Zn}$ changed little (Fig. 3), but total $\mathrm{Zn}$ increased significantly at $20-40 \mathrm{~cm}$, and this may be related to soil leaching. Unlike the change to asparagus production, total $\mathrm{Cd}$ decreased in the top $20 \mathrm{~cm}$ but increased between 20 and $80 \mathrm{~cm}$ with this type of land use change. The changes in heavy metals under land use from paddy soil (control 3) to mustard production were similar to viticulture (Fig. 4), except that total $\mathrm{Zn}$ and total $\mathrm{Cd}$ increased, even in the top $20 \mathrm{~cm}$.

Changes in available heavy metals down the soil profile under the three new land use types are presented in Figs. 5, 6, 7. The changes in soil profile available heavy metals were similar to those of the total heavy metals, with the highest values in the surface soil. The concentrations changed markedly from 0 to $40 \mathrm{~cm}$ depth but became stable below $40 \mathrm{~cm}$.

Available $\mathrm{Cu}$ decreased significantly only in the top $20 \mathrm{~cm}$ of the soil in 8-year-old fields after land use change to asparagus production (Fig. 5), and there were no significant differences after 13 and 23 years of cultivation compared with control 1 . However, significant increases were found in available $\mathrm{Zn}$ with increasing cultivation time in the top two layers of the soil profile which was similar to total $\mathrm{Zn}$. The distribution of available $\mathrm{Cd}$ in the soil profile differed from total $\mathrm{Cd}$, with no significant differences being found among the four treatments in the surface soil. There were much larger changes in available heavy metals down the soil profile after change to viticulture (Fig. 6). Available $\mathrm{Cu}$ and $\mathrm{Zn}$ increased with increasing depth to $80 \mathrm{~cm}$ in the soil profile which may be related to the significant decreases in soil $\mathrm{pH}$ (Table 4). However, the changes in available $\mathrm{Cd}$ were different, decreasing in the surface soil but increasing significantly deeper in the profile. After land use change to field mustard cropping (Fig. 7), the concentrations of available $\mathrm{Zn}$ increased significantly at all depths, but the effect decreased with increasing soil depth and there were no significant differences in available $\mathrm{Cu}$. The distribution of available $\mathrm{Cd}$ in the surface soil was similar to that in vineyards, with both decreasing significantly.

Changes in soil profile tetracycline content after change to different land use types

Concentrations of the four tetracyclines under different land use types are presented in Table 5. All four compounds were
Fig. 6 a-c Changes in soil profile $\mathrm{HCl}$-extractable heavy metal concentrations under different land use types. b Vineyards
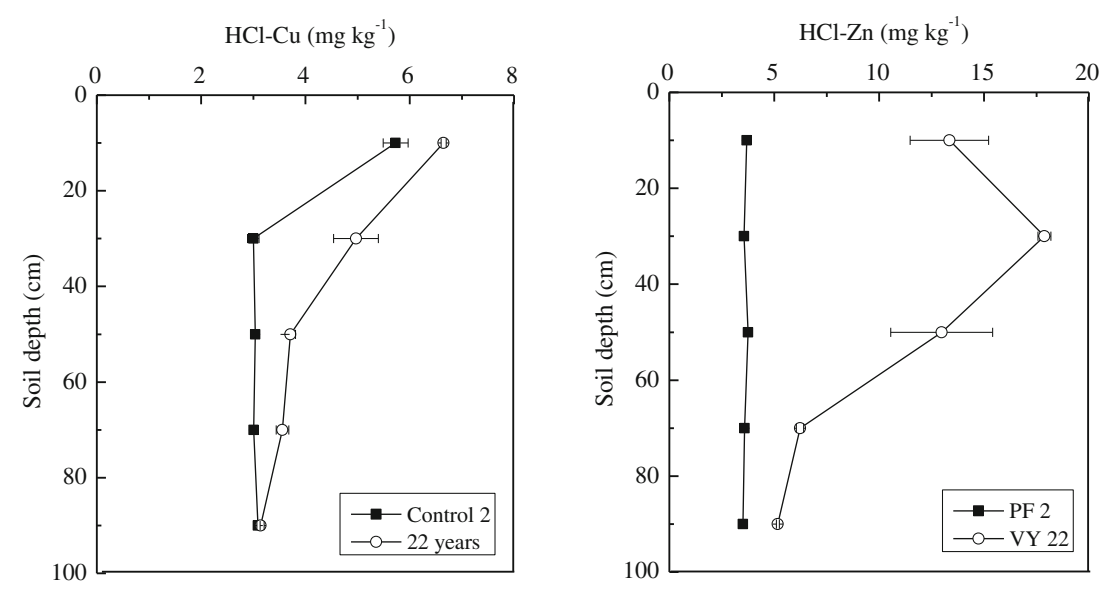

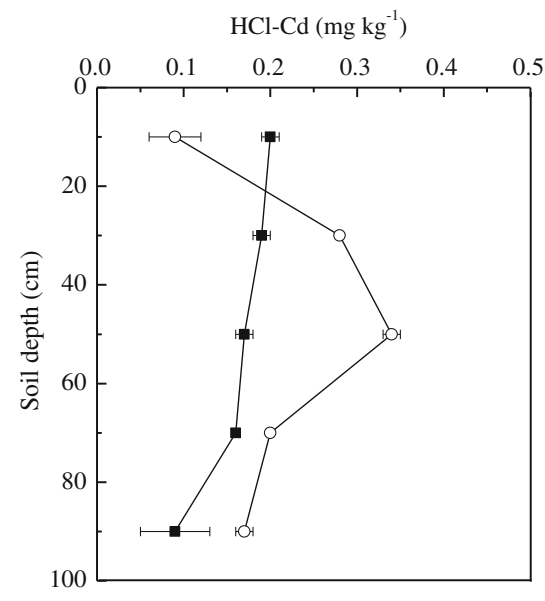


Fig. 7 a-c Changes in soil profile $\mathrm{HCl}$-extractable heavy metal concentrations under different land use types. c

Mustard fields
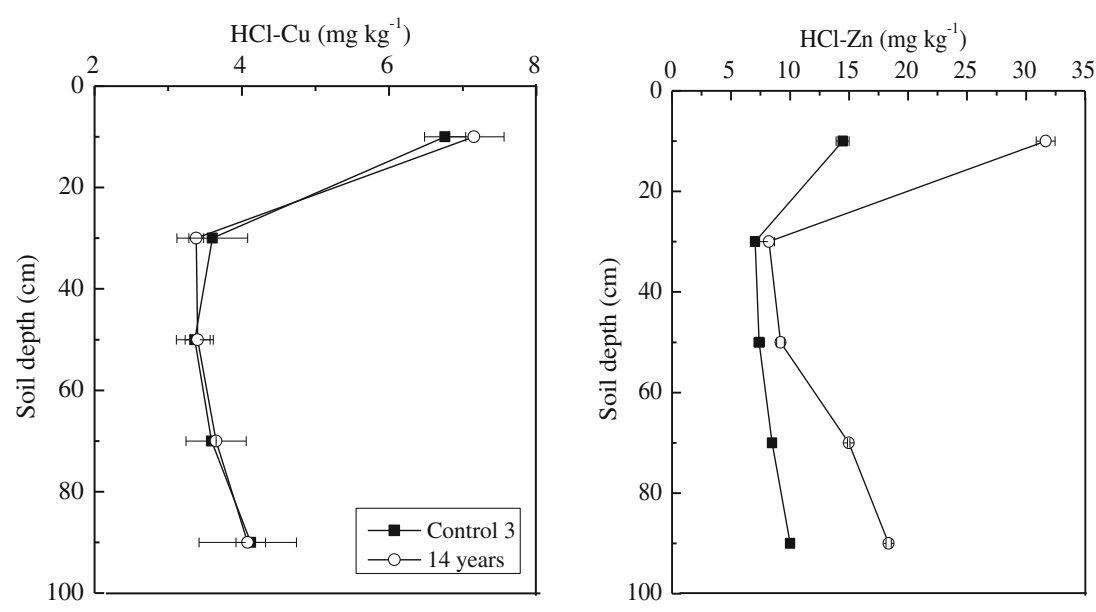

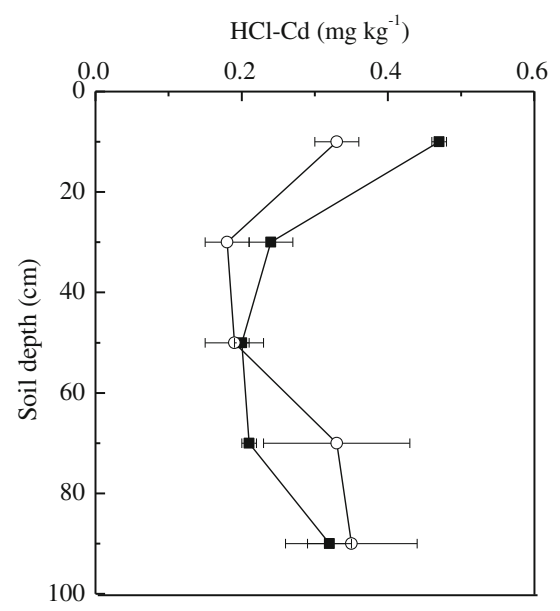

detected in soil samples and, similar to the heavy metals, their concentrations after 14 years of mustard growing were highest with a mean of $\sum \mathrm{TC}$ concentration of $22.9 \mu \mathrm{g} \mathrm{kg}^{-1}$, lower than reported from other studies (Hamscher et al. 2006; Li et al. 2011). The higher contents of tetracyclines in the top $20 \mathrm{~cm}$ than at $20-40 \mathrm{~cm}$ depth may have been due to their strong adsorption in the soil reducing their mobility (Tolls 2001; Sassman et al. 2005).

After land use change to asparagus production, with increasing cultivation time the concentrations of TCs (TC, OTC, CTC and DOC) in the top $20 \mathrm{~cm}$ increased and reached their highest values with mean values of $1.50,6.72,1.70$ and $16.4 \mu \mathrm{g} \mathrm{kg}^{-1}$, respectively, in a 13-year-old field, but decreased again in a 23-year-old field throughout the soil profile. This may be related to the ratio of input and degradation of the antibiotics. The antibiotic that showed the largest increase was DOC, with 78.1 and 8.75 times the control values at 0-20 and 20-40 cm depths, respectively, in a field cultivated for 13 years. There was no significant difference in TCs down to $40 \mathrm{~cm}$ depth after change to viticulture, likely because little manure was applied. After land use change to mustard cropping, there were significant increases only in TC and CTC with 3.48 and
28.9 times control values, respectively, and this resulted in an increase in $\sum \mathrm{TCs}$ in the top $20 \mathrm{~cm}$ of the soil profile.

\section{Discussion}

Heavy metals in soil after change to different land use types

Heavy metals in surface soil

In general, heavy metal pollution in agricultural land is mainly derived from the deposition of particulate pollutants from industry, transportation and urban human activities which contaminate the soil in the surrounding areas, from irrigation with untreated municipal sewage and intensive (including excessive) application of fertilisers and pesticides (Zhou et al. 2008). In the present study, land application of manures was intended to be the most important factor. The excessive use of manures from intensive farming enterprises can lead to the accumulation of heavy metals in surface soil, and the nature of the contamination is related to the type of heavy metal, type of land use, quantity of fertiliser applied, 


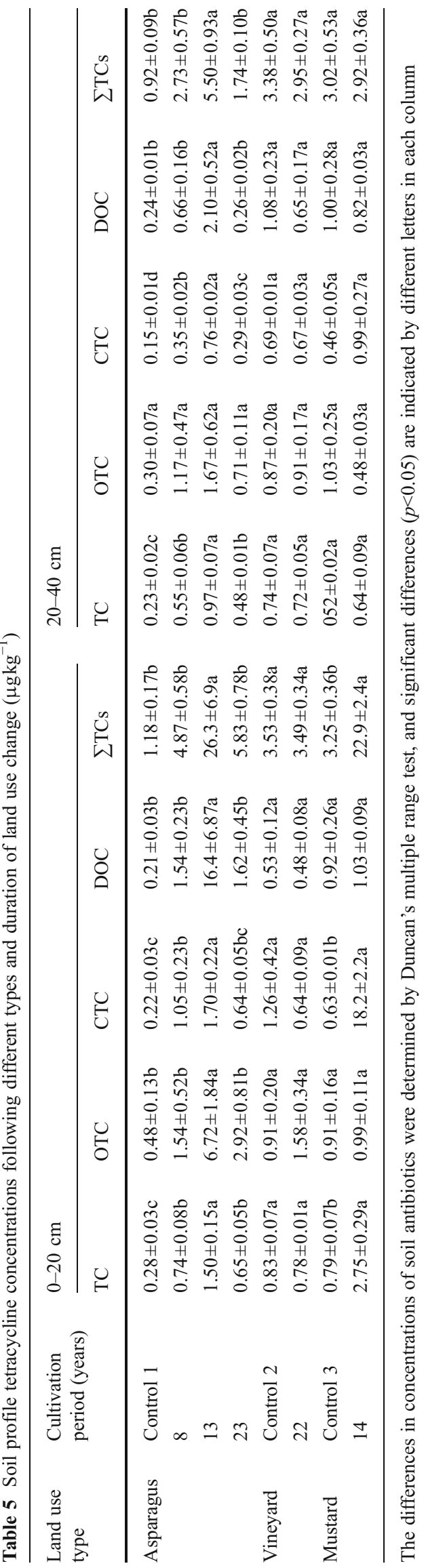

background values and cultivation period. In the case of total $\mathrm{Cu}$, the sequence was field mustard $>$ vineyards $>$ asparagus fields when duration of land use change was considered. Although the concentrations of heavy metals in surface soil usually did not exceed the grade II limit of the Soil Environmental Quality Standards, significant increases were still found after land use change, suggesting some potential risk and possible effects on the quality of agricultural products (Huang et al. 2007). The use of copper sulphate as a fungicide may have contributed to the $\mathrm{Cu}$ concentrations found in the soils where the land use had changed to vineyard systems.

\section{Heavy metals down the soil profile}

Significant increases in concentrations of heavy metals are found mostly in the top $20 \mathrm{~cm}$ of the soil profile and several metals extend down to $20-40 \mathrm{~cm}$, indicating that they represent anthropogenic pollution (Zhou et al. 2008). It would appear that heavy metals in soils will increase if manure is used as the main source of plant nutrients. However, accumulation is usually mostly in surface soils, and this may have deleterious effects on most plant species without any detectable effect on ground water quality. In the present study, the total fractions of the heavy metals studied generally increased after land use change from cereal production to vegetable cultivation or viticulture, but the results for available fractions differed among the metals, with available Cd usually decreasing in the surface soil irrespective of the new type of land use. The effects of different land use changes on the same metal also differed with different soil management and crop species. Soil heavy metal pollution will be related to the type of manure used and type of change in land use.

Soil tetracyclines

The type and quantity of tetracycline residues in soil also differed after different land use changes and were also related to farming management (Blackwell et al. 2009).

Table 6 Correlation coefficients between the concentrations of heavy metals and TCs after different duration of change from paddy rice to asparagus production

\begin{tabular}{|c|c|c|c|c|c|}
\hline Variable & Cultivation time & $\mathrm{Cu}$ & $\mathrm{Zn}$ & $\mathrm{Cd}$ & $\sum \mathrm{TCs}$ \\
\hline $\begin{array}{l}\text { Cultivation } \\
\text { time }\end{array}$ & 1 & & & & \\
\hline $\mathrm{Cu}$ & $0.688^{*}$ & 1 & & & \\
\hline $\mathrm{Zn}$ & $0.785^{* *}$ & $0.884 * *$ & 1 & & \\
\hline $\mathrm{Cd}$ & $0.649^{*}$ & 0.423 & 0.372 & 1 & \\
\hline$\sum \mathrm{TCs}$ & 0.259 & $0.747 * *$ & $0.645^{*}$ & 0.051 & 1 \\
\hline
\end{tabular}

$R$ values (correlation coefficients) are significant at $* p<0.05$ or $* * p<0.01$ 
Comparing the four tetracyclines, OTC and DOC were dominant in the soil in which asparagus was produced, OTC was dominant in vineyards and CTC was dominant in mustard soils. This may also be related to significant differences in the degradation of organic pollutants in soils growing different crop species and may be related to differences in plant physiological and biochemical properties. As a result of manure use, the antibiotics were found in the surface soil where their concentrations increased very significantly compared to unused farmland and were also detectable at a depth of $20-40 \mathrm{~cm}$ down the profile, and increasing amounts of manure applied and cultivation time led to continued increase and movement down the soil profile of the residues.

Relationship between soil heavy metals and tetracyclines under different types of land use change

Application of manures in farmland may lead to combined contamination of soils with heavy metals and antibiotics, but there are few studies of combined pollution. The present study therefore included both metals and tetracyclines in the surface soils of asparagus fields. Table 6 indicates that combined pollution with heavy metals and TCs was present in the asparagus fields and was affected by cultivation time, and this was substantiated by the correlation coefficients obtained for the three metals and $\sum \mathrm{TC}$ s considered. Significant correlations were found between pollutants and cultivation times except $\sum \mathrm{TCs}$ which were discussed in detail in earlier sections above. There were positive relationships among $\mathrm{Cu}, \mathrm{Zn}$ and $\sum \mathrm{TCs}$, especially between $\mathrm{Cu}$ and either $\mathrm{Zn}$ or $\mathrm{Cu}$ and $\sum \mathrm{TCs}$, and these may have been important feed additives (Poulsen 1998; Sarmah et al. 2006). Thus, in this region manure application may be likely to result in combined contamination of agricultural soils with $\mathrm{Cu}, \mathrm{Zn}$ and $\sum \mathrm{TCs}$.

\section{Conclusions}

Combined contamination with heavy metals and TCs was found in farmland soils as a result of the excessive use of manures from intensive farming systems, and there was a positive relationship among $\mathrm{Cu}, \mathrm{Zn}$ and $\sum \mathrm{TCs}$. The type and quantity of pollutant residues in soil differed in different land use types; OTC and DOC were dominant in soils used for asparagus production, OTC was dominant in vineyards and CTC was dominant in mustard soils. The background values in soils and the cultivation period of the crops also affected the accumulation of the pollutants. Significant increases in heavy metals and tetracycline concentrations were found mostly in the top $20 \mathrm{~cm}$ of the soil profile and some extended deeper to $20-40 \mathrm{~cm}$, and increasing manure application rate and cultivation time led to continuing increases in residue concentrations and movement down the soil profile.

Acknowledgements This research was supported by the National Natural Science Foundation of China (Project 40930739) and the National High-Technology Research and Development Program of China (Project 2012AA06A204).

\section{References}

Abaye DA, Lawlor K, Hirsch PR, Brookes PC (2005) Changes in the microbial community of an arable soil caused by long-term metal contamination. Eur J Soil Sci 56:93-102

Arthur JR, Bremner I, Chesters JK (1982) Trace elements in animal nutrition. Inorg Biochem 3:344-371

Berenguer P, Cela S, Santiveri F, Boixadera J, Lloveras J (2008) Copper and zinc soil accumulation and plant concentration in irrigated maize fertilized with liquid swine manure. Agron $\mathrm{J}$ 100:1056-1061

Blackwell PA, Kay P, Ashauer R, Boxall ABA (2009) Effects of agricultural conditions on the leaching behaviour of veterinary antibiotics in soils. Chemosphere 75:13-19

Bolan NS, Adriano DC, Mahimairaja S (2004) Distribution and bioavailability of trace elements in livestock and poultry manure byproducts. Crit Rev Env Sci Tech 34:291-338

Bound JP, Voulvoulis N (2004) Pharmaceuticals in the aquatic environment-a comparison of risk assessment strategies. Chemosphere 56:1143-1155

Boxall ABA, Kolpin DW, Halling-Sorensen B, Tolls J (2003) Are veterinary medicines causing environmental risk? Environ Sci Technol 37:286A-294A

Brambilla G, Patrizii M, De Filippis SP, Bonazzi G, Mantovi P, Barchi D, Migliore L (2007) Oxytetracycline as environmental contaminant in arable lands. Anal Chim Acta 586:326-329

Chee-Sanford JC, Mackie RI, Koike S, Krapac IG, Lin YF, Yannarell AC, Maxwell S, Aminov RI (2009) Fate and transport of antibiotic residues and antibiotic resistance genes following land application of manure waste. J Environ Qual 38:1086-1108

Chen YS, Zhang HB, Luo YM, Song J (2012a) Occurrence and assessment of veterinary antibiotics in swine manures: a case study in East China. Chinese Sci Bull 57:606-614

Chen YS, Zhang HB, Luo YM, Song J (2012b) Occurrence and dissipation of veterinary antibiotics in two typical swine wastewater treatment systems in east China. Environ Monit Assess 184:2205-2217

Cooperative Research Group on Chinese Soil Taxonomy. Chinese Soil Taxonomy. Science Press, Beijing, 2001, p. 83.

Fernandez-Calvino D, Novoa-Munoz JC, Lopez-Periago E, AriasEstevez M (2008) Changes in copper content and distribution in young, old and abandoned vineyard acid soils due to land use changes. Land Degrad Dev 19:165-177

Halling-Sorensen B, Nielsen SN, Lanzky PF, Ingerslev F, Lutzhoft HCH, Jorgensen SE (1998) Occurrence, fate and effects of pharmaceutical substances in the environment - a review. Chemosphere 36:357394

Hamscher G, Paweizick HT, Hoper H, Nau H (2006) Different behaviour of tetracyclines and sulfonamides in sandy soils after repeated fertilization with liquid manure. Environ Toxicol Chem 24:861-868

Hamscher G, Sczesny S, Hoper H, Nau H (2002) Determination of persistent tetracycline residues in soil fertilized with liquid manure 
by high-performance liquid chromatography with electrospray ionization tandem mass spectrometry. Anal Chem 74:1509-1518

Hu XG, Zhou QX, Luo Y (2010) Occurrence and source analysis of typical veterinary antibiotics in manure, soil, vegetables and groundwater from organic vegetable bases, northern China. Environ Pollut 158:2992-2998

Huang S, Liao QL, Hua M, Wu XM, Bi KS, Yan CY, Chen B, Zhang XY (2007) Survey of heavy metal pollution and assessment of agricultural soil in Yangzhong district, Jiangsu Province, China. Chemosphere 67:2148-2155

Kirchmann H, Thorvaldsson G (2000) Challenging targets for future agriculture. Eur J Agron 12:145-161

Knapp CW, Dolfing J, Ehlert PAI, Graham DW (2010) Evidence of increasing antibiotic resistance gene abundances in archived soils since 1940. Environ Sci Technol 44:580-587

Kornegay ET, Hedges JD, Martens DC, Kramer CY (1976) Effect of soil and plant mineral levels following application of manures of different copper levels. Plant Soil 45:151-162

Kumpiene J, Lagerkvist A, Maurice C (2008) Stabilization of As, Cr, $\mathrm{Cu}, \mathrm{Pb}$ and $\mathrm{Zn}$ in soil using amendments - a review. Waste Manage 28:215-225

Kumar K, Gupta SC, Baidoo SK, Chander Y, Rosen CJ (2005a) Antibiotic uptake by plants from soil fertilized with animal manure. J Environ Qual 34:2082-2085

Kumar K, Gupta SC, Chander Y, Singh AK (2005b) Antibiotic use in agriculture and its impact on the terrestrial environment. Adv Agron 87:1-54

Li YW, Wu XL, Mo CH, Tai YP, Huang XP, Xiang L (2011) Investigation of sulfonamide, tetracycline, and quinolone antibiotics in vegetable farmland soil in the Pearl River Delta area, Southern China. J Agric Food Chem 59:7268-7276

Lopes C, Herva M, Franco-Uria A, Roca E (2011) Inventory of heavy metal content in organic waste applied as fertilizer in agriculture: evaluating the risk of transfer into the food chain. Environ Sci Pollut R 18:918-939

Martinez JL (2008) Antibiotics and antibiotic resistance genes in natural environments. Science 321:365-367

McGrath SP, Cunliffe CH (1985) A simplified method for the extraction of the metals $\mathrm{Fe}, \mathrm{Zn}, \mathrm{Cu}, \mathrm{Ni}, \mathrm{Cd}, \mathrm{Pb}, \mathrm{Cr}$, Co and $\mathrm{Mn}$ from soils and sewage sludges. J Sci Food Agric 36:794-798

Nicholson FA, Chambers BJ, Williams JR, Unwin RJ (1999) Heavy metal contents of livestock feeds and animal manures in England and Wales. Bioresource Technol 70:23-31

Nicholson FA, Smith SR, Alloway BJ, Carlton-Smith C, Chambers BJ (2003) An inventory of heavy metals inputs to agricultural soils in England and Wales. Sci Total Environ 311:205-219

Phillips I, Casewell M, Cox T, De Groot B, Friis C, Jones R, Nightingale C, Preston R, Waddell J (2004) Does the use of antibiotics in food animals pose a risk to human health? A critical review of published data. J Antimicrob Chemother 53:28-52

Pinamonti F, Stringari G, Gasperi F, Zorzi G (1997) The use of compost: its effects on heavy metal levels in soil and plants. Resource Conserv Recycl 21:129-143

Poulsen HD (1998) Zinc and copper as feed additives, growth factors or unwanted environmental factors. J Anim Feed Sci $7: 135-142$

Sarmah AK, Meyer MT, Boxall ABA (2006) A global perspective on the use, sales, exposure pathways, occurrence, fate and effects of veterinary antibiotics (VAs) in the environment. Chemosphere 65:725-759

Sassman SA, Lee LS (2005) Sorption of three tetracyclines by several soils: assessing the role of $\mathrm{pH}$ and cation exchange. Environ Sci Technol 39:7452-7459

Shi Z, Wang RC, Huang MX (2002) Detection of coastal saline land use with multi-temporal Landsat images in Shangyu City, China. Environ Manage 30:142-150

State Environmental Protection Administration of China, SEPA, Environmental Quality Standards for Soils (GB15618-1995), 1995, www.sepa.gov.cn/english/index.php3.

Tolls J (2001) Sorption of veterinary pharmaceuticals in soils: a review. Environ Sci Technol 5:3397-3406

Tufft LS, Nockels CF (1991) The effects of stress, Escherichia coli, dietary ethylene diamine tetraacetic acid, and their interaction on tissue trace elements in chicks. Poultry Sci 70:2439 2449

Veeken A, Hamelers B (2002) Sources of $\mathrm{Cd}, \mathrm{Cu}, \mathrm{Pb}$ and $\mathrm{Zn}$ in biowaste. Sci Total Environ 300:87-98

Voundi Nkana JC, Tonye J (2003) Assessment of certain soil properties related to different land-use systems in the Kaya watershed of the humid forest zone of Cameroon. Land Degrad Dev 14:57-67

Wei X, Wu SC, Nie XP, Yediler A, Wong MH (2009) The effects of residual tetracycline on soil enzymatic activities and plant growth. J Environ Sci Health Part B 44:461-471

Wu LH, Tan CY, Liu L, Zhu P, Peng C, Luo YM, Christie P (2012) Cadmium bioavailability in surface soils receiving long-term applications of inorganic fertilizers and pig manures. Geoderma 173-174:224-230

Zhao L, Dong YH, Wang H (2010) Residues of veterinary antibiotics in manures from feedlot livestock in eight provinces of China. Sci Total Environ 408:1069-1075

Zhou QX, Zhang QR, Sun TH (2006) Technical innovation of land treatment systems for municipal wastewater in northeast China. Pedosphere 16:297-303

Zhou SL, Liao FQ, Wu SH, Zhang HF, Ren K (2008) Heavy metals contents in soil profiles of typical agricultural lands in Yixing, Jiangsu Province, China. Chinese Sci Bull 53:177-187 